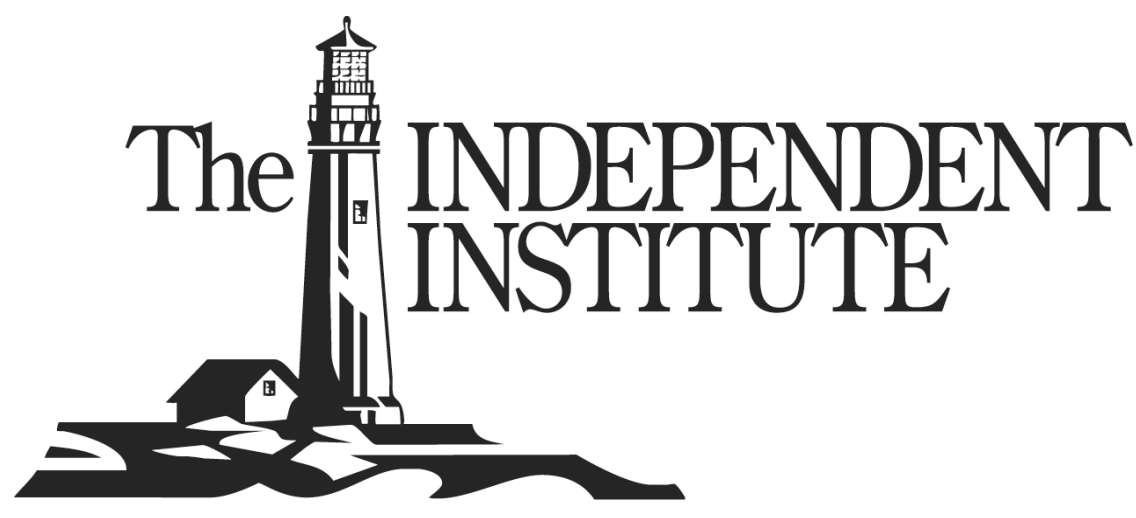

\title{
Somalia After State Collapse: Chaos or Improvement?
}

\author{
Benjamin Powell \\ Ryan Ford \\ Alex Nowrasteh
}

Independent Institute Working Paper Number 64

November 30, 2006

Benjamin Powell is an Assistant Professor of Economics at San Jose State University and the Director of the Center on Entrepreneurial Innovation at the Independent Institute. Ryan Ford is a graduate student of economics at San Jose State University. Alex Nowrasteh is an economics major at George Mason University. 
Somalia After State Collapse: Chaos or Improvement?

\author{
Benjamin Powell \\ Ryan Ford \\ Alex Nowrasteh*
}

\begin{abstract}
Many people believe that Somalia's economy has been in chaos since the collapse of its national government in 1991. We take a comparative institutional approach to examine Somalia's performance relative to other African countries both when Somalia had a government and during its extended period of anarchy. We find that although Somalia is poor, its relative economic performance has improved during its period of statelessness. We also describe how Somalia has provided basic law and order and a currency, which have enabled the country to achieve the coordination that has led to improvements in its standard of living.
\end{abstract}

JEL Codes: O10, O17, O57, P16, P50

Key Words: Somalia, Anarchy, Economic Development, Africa

\footnotetext{
* Benjamin Powell is an Assistant Professor of Economics at San Jose State University and the Director of the Center on Entrepreneurial Innovation at the Independent Institute. Ryan Ford is a graduate student of economics at San Jose State University. Alex Nowrasteh is an economics major at George Mason University.
} 
Somalia has lacked a national government since the fall of Siad Barre's dictatorship in 1991. Rival factions immediately plunged the country into civil war in failed attempts to install themselves as the new national government. U.S. and UN humanitarian and military intervention from 1993 through 1995 failed to restore peace. In fact, the Somalis united against the foreign presence and eventually forced the U.S. to withdraw. Since the U.S. withdrawal episodes of criminal behavior and violence have occurred, but not at the levels seen when factions vied to control a single government. In fact, with the relative peace, there is evidence that Somalia has been able to increase its standard of living while remaining stateless.

Somalia's extended period without a national government in the modern era provides us with a unique opportunity to study the political economy of a stateless order. Some theorists (Hobbes 1651, Buchanan 1975) have argued that without a government society would plunge into a war of all against all, the result of which would be a life that is "nasty, brutish, and short." In the absence of a complete collapse, standard economic theory still predicts that many public goods and more complex market transactions would not be provided. On the other hand, a few theorists (Rothbard 1973, Friedman 1989) have contended that a stateless "anarcho-capitalist" society could provide essential public goods and maintain a high standard of living.

Somalia's experience fails to conform to any of these theories perfectly. Despite the initial violence, the country is relatively peaceful now, and living standards have not collapsed. Some public goods are being provided with more success than others. But 
Somalia fails to live up to the thriving economy predicted by anarcho-capitalists. The Somali experience does, however, provide insight to the robustness of markets when states collapse.

This paper approaches Somalia from a comparative institutional perspective. Somalia's achievements in a stateless order are compared to its performance when it had a state as well as to the performance of neighboring African states. Most African nation states are far from governments that only correct market failures and provide the background institutions for markets to operate. In fact, George Ayittey (1998) refers to many African countries as "vampire states" that suck the life-blood out of the population for the benefit of the rulers. Somali anarchy also falls far short of the ideal stateless institutional environment anticipated by Rothbard and Friedman. This paper compares these imperfect institutions in Somalia and Africa. Somalia's experience can inform both political economy theory and African development policy.

Although some standard data are available, much of the traditional data economists use to measure development is lacking in Somalia. In this paper we use traditional measures when available as well as ethnographic and anecdotal evidence from work in other social sciences. Our paper proceeds as follows. The next section provides some background on the major events leading up to the collapse of the Somali state and its economic performance under a national government. Section III examines data on living standards and economic activity to compare Somalia's performance while stateless to when it had a state and to other African countries. Section IV describes how Somalia has produced public goods and other complex market transactions without a state. Section V contains conclusions. 


\section{Somalia Before State Collapse}

Somalia contains a patchwork of different clans and ethnic groups. Prior to independence, Britain governed the northern region, Somaliland, while Italy ruled the southern region. When Somalia became independent in the 1960s, no sense of national identity existed. Different languages, monetary systems, and styles of government all made central governance difficult. Somalis preferred to be known as Isaaq, Darood, or Bantu rather than Somali because loyalty to one's clan, village, and ethnicity took precedence over loyalty to the national government (Federal Research Division 1993). Secret votes by National Assembly members based on clan lineage increasingly demonstrated that the Somali democracy was not functioning well.

In 1969 a military coup assassinated the president and closed down the parliament. The constitution was abolished, and General Siad Barre became dictator. Shortly after taking power, Barre announced that the new regime's goals would be to put an end to "tribalism, nepotism, corruption, and misrule," and that those goals would be achieved through the application of "Scientific Socialism."

The creation of a command economy to control resources and to funnel power and wealth to political supporters was of paramount importance in the Barre regime. Goods, capital, and arms supplied by the Soviet Union and other communist countries helped accomplish this (Besteman 1996: 581). Although Barre had outlawed the use of any terminology referring to the clans, he illegally gave land and water rights to specific clans that supported his rule (Besteman 1996: 126). 
Most Somalis were rural pastoralists or small farmers who traded their produce across Africa and the Middle East on complicated but time-proven trade routes. Since political power was concentrated in urban cities, these rural Somalis had little influence in shaping Barre's policies and were routinely mistreated. Beginning in the 1970s, for example, state laws nationalized access to land and water as well as imposed severe restrictions on the livestock and qat (a popular stimulant) trades, stripping the nomads and rural farmers of their productive assets (Besteman 1996: 127). By making statecontrolled title registration the only legal way to hold land, the land tenure laws of the 1970s and 1980s quickly resulted in the nationalization of the nation's most fertile and densely populated farmland. This land was then transferred to small cliques of politicians or politically connected businessmen. In some cases entire villages of local farmers in the North, and to a lesser extent in the South, became victims of Barre's scientific socialism (Besteman. 1996: 127).

The state became the primary means to achieve wealth because the private market was systematically regulated and destroyed by bureaucrats. People increasingly had to turn to state aid to meet their basic survival needs. In 1978 the regime started its political decline, and massive aid from the Soviet Union ceased because of Somalia's war with another Soviet satellite, Ethiopia. This increased the competition between urban bureaucrats and rural farmers for state resources, leaving the countryside in shambles. The chaos of Somalia's failing economy was made worse by the addition of hundreds of thousands of refugees after Somalia's defeat in the Ogaadeen War.

A major program to resettle all refugees started immediately after Somalia's defeat in the Ogaadeen War. By 1981, 700,000 refugees were being resettled in the 
North to weaken the Isaaq clan, which was openly resisting Barre's regime (Schraeder: 647). The northern clans, primarily made up of the Isaaq, were non-hierarchical pastoralists who resisted government attempts at centralization and increased control; the southern clans were more open to political manipulation because of years of political favors and government money (Schraeder: 648). As refugees displaced northern farmers and the government confiscated ever-larger tracts of land for their resettlement, fighting broke out between the malnourished refugees, the Somali Armed Forces, and the dispossessed farmers. This eventually led to the 1991 civil war. As resettlement continued in the north, it became clear that areas in the South and around Mogadishu would need to be opened for resettlement if all refugees were to receive land. This upset the southern clans, which were previously loyal to Barre's regime, and an insurgency began shortly after the arrival of the first refugees (Schraeder: 651).

Dismal economic performance accompanied the growing political turmoil in Somalia while it was governed by the national government. Socialism was formally abandoned in 1980, but economic policy did not improve. Government interventions hampered market transactions and racked up public debt while providing few benefits to the average citizen.

Throughout the 1970s and 1980s, the government did conduct a large public investment program, but it was unproductive and created much public debt (Mubarak 1997: 2028). In 1989 the consolidated non-financial public sector deficit was 37 percent of GDP; by 1990 the total outstanding foreign debt was 277 percent of GDP (Mubarak 1997:2028). The population received few benefits from this spending. About 90 percent 
of spending was on defense and administration while spending on social services fell to less than 1 percent of GDP during 1988-1989 (Mubarak 1997: 2028).

The banking industry was also in shambles. As Mubarak puts it,

In the 1970s and early 1980s the banking system was largely a financing tool for public agencies... The Commercial and Savings Bank was declared bankrupt, and the Development Bank was unable to provide new lending in 1989. The financial system fell into deep crisis and, with the complicity of corrupt officials, most of the daily operations of the banking system fell to the black market (1997: 2028-2029).

As the public sector failed to provide goods and services during the 1980s, informal black markets expanded to fill the void. The informal sector replaced former government monopolies by providing financial, health, and educational services. For example, the informal sector, "provided credit and investment-financing to small producers, since access to the official credit market was granted only to state monopolies and businessmen with political connections. It facilitated the channeling of remittances by Somalis living abroad and gave private traders access to the foreign exchange" (Mubarak 1997: 2029). Overall, by the mid-1980s, the informal black market sector was the largest employer of labor (Mubarak 1997: 2029).

In addition, the rural pastoral sector saw particularly few benefits from the national government. The pastoralists employed 70 percent of the labor force and produced 65 percent of the GDP, but only 6 percent of public spending (1.2 percent of GDP) was directed to the sector annually from 1974-1988 (Mubarak 1997: 2029). Most rural pastoralists were either exploited or ignored by Barre's national government. As Little (2003) put it, in rural areas, "the state was an entity that extracted some local resources and was punitive at times, but could not be counted on to govern daily affairs" (p.16). 
The Somali national government existed largely to benefit Barre and his allies rather than the average Somali. In fact, the average standard of living was so low that Somalia had one of the lowest per capita food intakes during the 1980s (Farzin 1988). The upside to the neglect and exploitation suffered under Barre's rule is that Somalis relied on traditional clan networks and informal markets to survive. These clan networks, which had existed for generations, and the new informal markets that emerged during the 1980s would play an important role in Somalia's economic performance after the national government collapsed in 1991.

III. Economy and Living Standards Without a State

After Barre's government collapsed in 1991, rival warlords plunged the country into civil war, each attempting to install himself as the new dictator. None was successful. After the UN withdrew in 1995, the prospect of a new national government being installed diminished, and so did the fighting. Although multiple governments in exile have been created, none has been able to establish its rule over a significant portion of the country. Today southern Somalia still lacks a regional government. In the north the regions of Somaliland and Puntland have declared their independence, though no national governments recognize them as states. These regional "governments" do provide some administrative services, but they might be better classified as clan-based governance than the type of national government we in the west conceive of.

While the civil war after the government collapsed hurt the economy and lowered living standards, since the achievement of a relative peace the economy has recovered. Mubarak finds that the Somali economy has suffered more from droughts and the civil war than from the loss of state institutions. Overall, he finds that, "as far as economic 
welfare is concerned, absence of government has proven to be better than the repressive institutions and improper policies of Barre's government" (1997: 2028). Little (2003) also finds that some sectors of the Somali economy are doing better than during the prewar years.

This is not to say that Somalia has a great business environment. As Little notes, "For the merchant today, there are still fees to be paid to greedy faction leaders and militia at ports and roadblocks but levels of taxation and trade restrictions are considerably below what they were pre-1991" (2003: 7-8). This section examines the comparative institutional question of how well the imperfect Somali anarchy performs compared to the imperfect Somali state pre-1991 and other imperfect African states. After examining the rural pastoralist sector of the Somali economy that was largely neglected by the Barre regime, we look for evidence of commercial business activity in urban areas. Finally, we examine general Somali living standards.

\section{The Pastoral Sector}

The pastoral sector was largely neglected or harmed by the central government. ${ }^{1}$ In the rural pastoral lands the government rarely constructed roads, health clinics or schools. The population didn't use the government to settle disputes or administer justice, and the government generally took more in revenue than it gave back in services (Little 2003:15). Not surprisingly, the pastoral sector has done quite well since the collapse of the central government. Herders who have always relied heavily on social relationships

\footnotetext{
${ }^{1}$ This subsection draws on the work of anthropologist Peter Little. His 2003 book, Somalia: Economy Without a State, focuses on the performance of the Somali pastoral sector and makes extensive use of ethnographic data, such as interviews, surveys, and field research, to uncover information that is not widely reported in traditional economic sources.
} 
and kinship to gain access to markets do so even more heavily now, and they do so without active government interference. The results are impressive.

The Somali live animal trade, which flows between neighboring Ethiopia and Kenya as well as to overseas markets, has increased dramatically. In Garissa, a major export market in Kenya for southern Somali cattle, the value of cattle sales increased 600 percent and the volume of sales quadrupled from 1989 to 1998 (Little 2003: 91). In the North animal trade from Somalia and neighboring land-locked Ethiopia flows to northern Somali ports for export. The two northern ports of Bossaso and Berbera exported nearly 3 million head of goat and sheep in 1999, accounting for 95 percent of all goat and 52 percent of all sheep exports for East Africa (Little 2003: 131). Overall, the volume of trade in sheep and goats in Somaliland and Puntland was greater in 1999 than when the regions were governed by a single national government. In fact, Somaliland is the leading exporter of livestock from eastern African nations (Little: 2003: 132). In 2002 Somalia as a whole exported more than 480 million metric tons of agricultural products and more than 180 million metric tons of livestock (Country Watch 2005: 40).

The livestock sector has experienced some problems, however. Droughts in particular have caused hardships, but this is true for the entire region, not just stateless Somalia. Little notes that, "Pockets of severe food insecurity remain in the Somali borderlands, but local herders have generally fared as well as - if not better than neighboring pastoral populations. Even with the devastating drought of 1999-2000, the food situation in Somalia was not markedly different from in other parts of the Horn of Africa" (Little 2003: 138). In fact, Somali herders did better than those in Kenya who saw nearly 50 percent of their cattle perish in recent droughts (Little 2003: 67). 
With the collapse of the government, some might be concerned that lack of security would raise transaction costs and prevent large-scale trade. However, in Somalia this has not happened. Although armed escorts are sometimes hired, transport costs per animal are usually less than $\$ 0.01 / \mathrm{km}$, and this price has not increased greatly since the collapse of the government (Little 2003: 103). In a 1998 survey of 84 rural pastoral traders, only 24 percent of respondents reported security related concerns, and only 13 percent thought security was more of a problem than it was in 1990 (Little 2003: 125). Since the rural pastoralists had traditional dispute resolution mechanisms to fall back on (see section IV), security has not been a major issue for herders since state collapse.

The health of the cattle trade is captured by quotes from interviews conducted by Little in 1996 and 1998, including:

'Since the fall of the government we have been doing well in livestock trade' [24 May 1996] (Little 2003: 125).

'During the government of Barre trade was worse, but now... it is a sort of free business’ [5 July 1998] (Little 2003: 128).

'These days livestock trade is not very good. The market is flooded with cattle from Ethiopia and Somalia' [18 May 1996] (Little 2003: 128).

The negative comment, typical of other complaints about prices that Little reports, still illustrates a booming market that has led to increased volume.

The overall performance of the rural pastoral sector in the absence of a state has been quite remarkable. Since the sector depended little on the state, and often suffered under it, pastoral Somalis have generally done better without a nation state than with one. 


\section{Commercial Business Activity}

Urban commercial business activity interacted more with the national government than the pastoral sector did. Cities have thus been more affected by the government's collapse. In some cities peace has been difficult to achieve. Where peace has been more stable, business activity remains strong. This section will examine major corporate business activity in Somalia as well as general business activity in the city of Borama.

Perhaps somewhat surprisingly for a poor, stateless, African country, Somalia has attracted a number of major corporations. Italian agribusiness companies and U.S.-based Dole Fruit Inc. have invested in the agricultural sector since the state's collapse. ${ }^{2}$ One of Somalia's media companies has affiliated with the British Broadcasting Corporation (BBC). The courier DHL serves Somalia. A British Airways affiliate flies to Somalia. General Motors also does business there. In 2004 Coca-Cola opened a soft drink plant in Mogadishu that will employ 120 Somalis and have a productive capacity of 36,000 bottles per hour (Ali 2004). Many companies avoid doing business in a number of Africa's nation states, so the fact that these international companies are willing to do business in Somalia is a strong indication that it has been successful in providing a minimum security of property rights and economic freedom.

Prior to colonialism many African regions had rural pastoral economies without a state, so the fact that Somalia's rural economy has been successful since state collapse is perhaps not surprising. What may be more remarkable is that cities, at least those that are relatively peaceful, have been able to maintain order and business activity without a state. Borama is one such city.

\footnotetext{
${ }^{2}$ All companies mentioned in this paragraph come from Little 2003: 166-167 unless otherwise cited.
} 
. Borama is located in the Awdal region of northwest Somalia in the unrecognized Republic of Somaliland. This region borders Djibouti, Ethopia, the Somaliland province of Woqooyi Galbeed, and the Gulf of Aden. The Somaliland government claims Awdal is part of Somaliland, but it is in fact a sovereign clan council ruled area (Davidson 2001). Adwal's most populous city is Borama, with a population ranging from 150,000 to 300,000 depending on season (Davidson 2001). Borama appears to have some type of tax collection for municipal works, as it is cited as having tax revenue of 958,225,000 Somaliland Shillings (roughly \$150,000 U.S. dollars) (Somaliland in Figures 2002: 23). How these funds are collected or what they are used for is not certain, but considering the city has a population of 300,000 , this is a rather small amount of taxation per capita. What is most interesting is that under clan leadership Adwal has thrived and created a reasonably high standard of living for its inhabitants.

Borama has a lot of commercial activity; the following figures are from eight years after the end to formal government in Awdal. Borama is home to 95 teashops, 82 restaurants of B, C, or D grade (non-star rated restaurants), 145 elementary shops, 8 star level restaurants, 69 wholesale stores, 106 retail stores, 137 clothing and shoe shops, 19 emporium shops, 30 retail pharmacy shops, 16 hotels ( 4 of which are star rated), 7 fuel stations with underground tanks, 4 with above ground tanks, and 10 selling fuel from barrels (Somaliland In Figures 1998). Borama also has a DHL drop off station (DHL 2005). The Borama airport was running nearly a flight a day as of 2001 (Somaliland In Figures 2002: 40). There are two hospitals that employ two laboratory technicians and an x-ray technician (Somaliland in Figures 2002: 64). A private university created in 1996 
now has more than 1,000 students, 45 teachers, and a library of more than 100,000 books (Amoud University 2006).

Borama illustrates that a large city with a variety of businesses can exist without a national government. The fact that international companies are willing to do business in stateless Somalia is also encouraging.

\section{Overall Living Standards}

As valuable as sectoral and city studies are, it is useful to examine broader standard of living measures to obtain a more accurate picture of Somalia's level of well being. This is no easy task given that no state exists to collect traditional data, and even when Somalia's state existed its data were often unreliable. We begin by reviewing other research on Somali living standards. We then use 13 measures from the World Bank's World Development Indicators that are available for a large cross section of African countries and in some cases are available over the past 20 years to examine how the Somali economy functioned over time compared to other countries.

This section builds on research comparing living standards conducted by Nenova and Harford (2004), Coyne (2006), and Leeson (2006). Nenova and Harford (2004) compared current living standards in Somalia with averages from neighboring Kenya, Eithiopia and Dijbouti as well as an average of 22 West African countries. They compared per capita income, Gini coefficients, percentage of the population living on less than PPP \$1 per day, roads and telephones per 1,000 population, the percentage of the population with access to safe drinking water, and the illiteracy rate. Of these seven measures they find that Somalia outperforms its neighbors on three of them (Gini 
coefficient, population living on less than $\$ 1$ a day, and telephones) and ties them on roads. Somalia outperforms and ties the West African average on the same measures. Coyne (2006) argues that reconstruction efforts focused on resolving the metalevel game of creating democratic governments fail because they neglect nested games embedded in the larger social construct. While using Somalia to illustrate this claim, he expands on Nenova and Harford (2004) by using additional standard of living measures from the U.N. Human Development Report to compare Somalia's current situation to its neighbors and West African countries. Coyne (2006) examines measures of income, health, children's health, telecommunications, and infrastructure. He finds that Somalia compares relatively well on measures of poverty and infrastructure provision. It has difficulty in health issues, but, "even on most of these [health] margins, Somalia is not drastically worse than comparative societies that possess a central government" (p.16).

Leeson (2006) builds on this literature by comparing how 18 development indicators have changed in Somalia since the collapse of the state. ${ }^{3}$ He assembles his data set from UNDP, World Bank, UNICEF, UNESCO, and World Health Organization reports, comparing data that they report for the last five years Somalia had a state, 198590, to those same measures for 2000-2005. Although the statistics clearly paint a picture of a very poor country, they also demonstrate that Somalia is doing better today without a state than when it last had one. Of the 18 development indicators, 13 clearly improved since the collapse of the state, and only two, adult literacy and school enrollment, clearly

\footnotetext{
${ }^{3}$ His measures consist of life expectancy, infant mortality, maternal mortality rate, infants with low birth weights, pop. with access to at least one health facility, pop. with access to treated water, pop. with access to sanitation, pop. living in extreme poverty, GDP per capita, one year olds immunized against TB, one year olds immunized against measles, fatality due to measles, doctors and nurses (per 1000), TVs (per 1000), radios (per 1000), telephones (per 1000), combined school enrollment, and adult literacy.
} 
declined. Leeson attributes the declines in these two measures to decreases in aid, not lack of state provision.

Leeson (2006) shows that while far from perfect, Somalia has not collapsed, and has actually improved in broad living standards since becoming stateless. To build upon this we examine Somalia's performance relative to a broader set of countries over time. We use the World Development Indicators to compare Somalia's performance with 42 other sub-Saharan African countries in both the current period and, when data allows, Somalia's relative performance over time. Other cross sectional studies do not address whether Somalia is continuing to improve, and Leeson's longitudinal study doesn't address how Somalia's economy evolved relative to other African countries that had states. In a general environment of growth, one should expect an economy to perform better on most measures after 20 years pass. Thus our comparison addresses a gap in the literature by establishing whether Somalia improved its relative performance once it shed its nation-state.

Unfortunately, using a broad cross section of countries over a 20 year time period for a region with often unreliable (or uncollected) data limits our metrics of comparison. We examine 13 measures: the death rate, infant mortality, life expectancy, child malnutrition, telephone mainlines, mobile phones, Internet users per 1000 population, households with television, DPT immunization, measles immunization, percent of the population with access to sanitation and an improved water source, and cases of tuberculosis. 


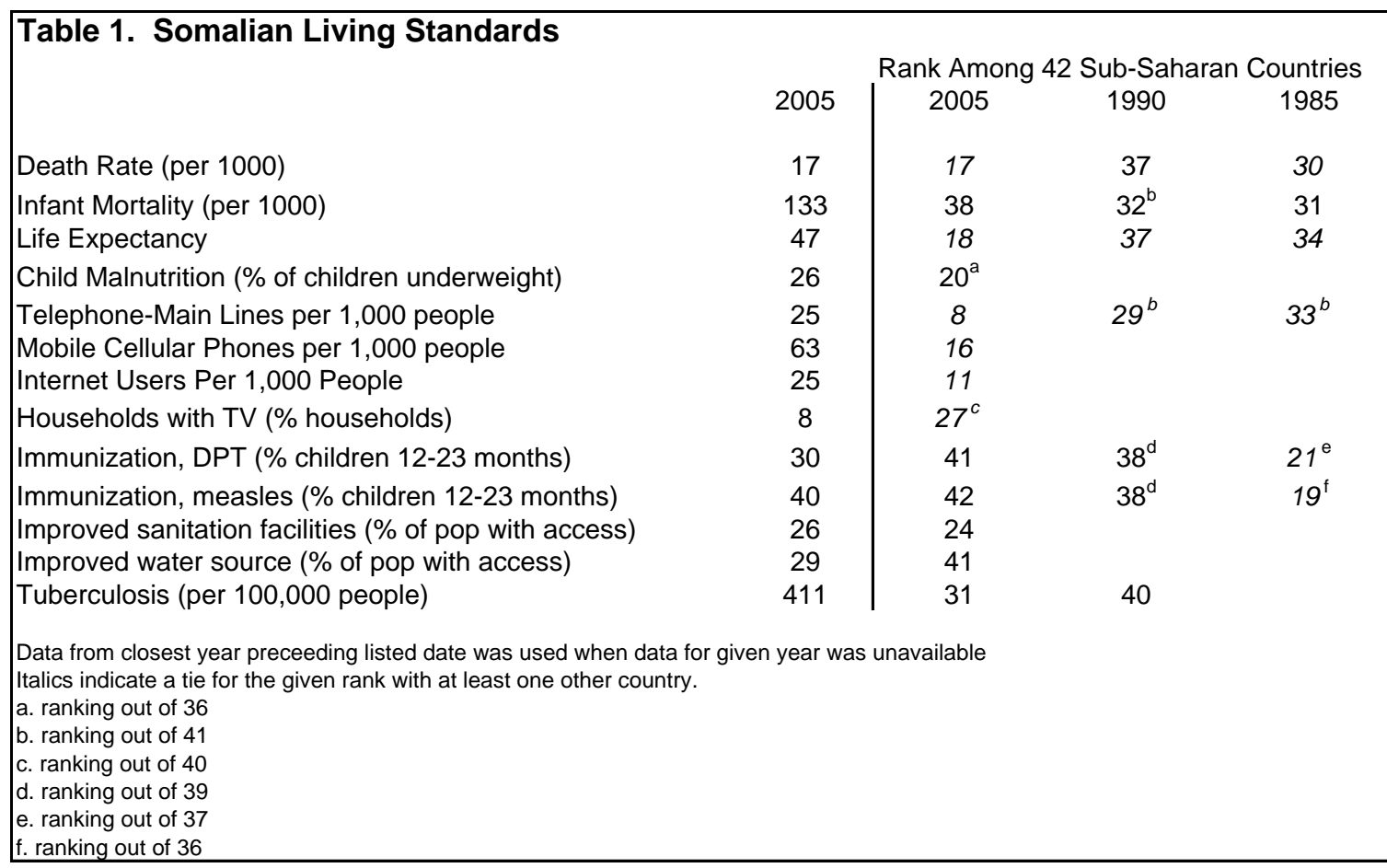

Although Somalia's 2005 standards of living are low by western standards, they compare fairly favorably with other African nations. Of our 13 measures, Somalia ranks in the top 50 percent of nations in six of them and only ranks near the bottom in infant mortality, immunization rates, and access to improved water sources. Although in 2005 the nation ranks in the bottom 50 percent of countries on seven measures, it has actually improved performance relative to other countries since the collapse of the Somali state. Somalia ranked in the bottom 50 percent of all seven variables for which we have 19851990 data. In the last years of the Somalian nation state (1985-1990), its performance relative to other African countries deteriorated from the early 1980s, with Somalia losing ground in life expectancy, death rate, and infant mortality as well as DPT and measles immunization. Only telephone main lines showed a slight improvement during this time.

Life expectancy in Somalia fell by two years from 1985 to 1990, but it has increased by five years since becoming stateless (1990-2005). Only three of the other 42 
countries improved life expectancy as much since 1990. While Somalia's infant mortality ranking has continued to slide, its death rate has improved, jumping from $37^{\text {th }}$ to $17^{\text {th }}$ since 1990 . While still in the bottom $50 \%$ in cases of tuberculosis, Somalia's relative rank has improved from $40^{\text {th }}$ to $31^{\text {st }}$ since the collapse of the government. Although Somalia's immunization rates for measles and DPT are among the lowest in Africa, its problems in this area existed before the collapse of the state. During the last five years of government rule Somalia's immunization rankings fell from $19^{\text {th }}$ and $21^{\text {st }}$, respectively, to next to last in both categories. While the country has stayed near the bottom of this ranking, the percentage of children immunized has improved. In 1990, 19 percent of children were immunized for DPT, and 30 percent were immunized for measles. In 2005 these numbers had improved to 30 percent and 40 percent, respectively. Although its rankings didn't improve, Somalia's rate of immunization relative to the median Sub-Saharan African country did. The percentage of Somali children immunized for DPT relative to the median improved from 30 percent of the median country in 1990 to 41 percent in 2005. For measles the percentages improved from 49 to 57 percent.

Access to improved water sources is a problem in Somalia. It ranks considerably better in access to improved sanitation facilities. Unfortunately, neither of these measures was available over a long enough time period to compare performance prior to the collapse of the state.

Telecommunications is one major area of success in Somalia. The one measure for which we have complete data, main lines per 1,000 of population, shows dramatic relative improvement since Somalia became stateless, moving from $29^{\text {th }}$ to $8^{\text {th }}$ among the African countries included in our survey. We only have data since the collapse of the 
state for mobile phone, Internet usage, and households with televisions. Somalia ranks highly in mobile phones $\left(16^{\text {th }}\right)$ and Internet users $\left(11^{\text {th }}\right)$, while it ranks $27^{\text {th }}$ in households with televisions. In many African countries state monopolies and licensing restrictions raise prices and slow the spread of telecommunications. In Somalia it takes just three days for a land-line to be installed; in neighboring Kenya waiting lists are many years long (Winter 2004). Once lines are installed, prices are relatively low. With a $\$ 10$ monthly fee, local calls are free, and international calls are only 50 cents per minute on land-lines; web access costs only 50 cents an hour (Winter 2004). According to the Economist, using a mobile phone in Somalia is "generally cheaper and clearer than a call from anywhere else in Africa" (2005: 89).

The collapse of the state has played a major role in the development of communications. Abdullahi Mohammed Hussein, a manager at Telecom Somalia, which was set up in 1994 when there was still fighting in Mogadishu, said, "The government post and telecoms company used to have a monopoly but after the regime was toppled, we were free to set up our own business" (Winter 2004). This freedom has led to intense competition in the Somali communication market and has resulted in low prices and good access to services by African standards.

Although all data from Somalia must be treated with some caution, when looking at these 13 measures of living standards, the overall picture seems clear. Somalia may be very poor, but the loss of its government does not appear to have harmed standards of living. On many measures Somalia compares favorably with the other 42 Sub-Saharan countries. Since losing its central government, we find that Somalia improved measures of well being both in absolute terms and relative to other African states. 


\section{Public Goods}

Urban businessmen, international corporations, and rural pastoralists have all functioned in stateless Somalia, achieving standards of living for the country that are equal or superior to many other African nations. The question is how. Foundation, or meta-market institutions, need to be in place for business to operate. At a minimum, laws that protect person and property, a dispute settlement process, and a currency are needed. People often assume that these are public goods that the government must provide. But the Somalis have managed to provide forms of all of these without a national government. Coyne (2006) identifies two main mechanisms that have allowed these types of goods to be provided: the use of clan and other local trust networks coupled with the simplification of transactions, and importing governance by relying on foreign institutions. In this section we examine how the Somalis provide law and order and a currency which allow the Somali economy to operate.

\section{Somali Law}

Somali law is based on custom, and decentralized clan networks interpret and enforce it. The Somali customary law (Xeer) has existed since pre-colonial times, and it continued to operate under colonial rule. The Somali nation state tried to replace the Xeer with government legislation and enforcement. However, in rural areas and border regions where the Somali government lacked firm control, people continued to apply the common law. When the Somali state collapsed, much of the population returned to their traditional legal system. ${ }^{4}$

The Xeer outlaws homicide, assault, torture, battery, rape, accidental wounding, kidnapping, abduction, robbery, burglary, theft, arson, extortion, fraud, and property 
damage (Van Notten 2005: 49). The legal system focuses on the restitution of victims, not the punishment of criminals. For violations of the law, maximum payments to compensate victims are specified in camels (payment can be made in equivalent monetary value). Typical compensation to the family of a murder victim is 100 camels for a man and 50 for a woman; an animal thief usually must return two animals for every one he stole. ${ }^{5}$

Clan elders chosen on the basis of their knowledge of the law judge cases. The elders cannot create the law. They only interpret the community customs. Elders who make decisions that deviate from community norms are not consulted in future cases. When a dispute arises between two members of different clans, their clan elders must reach a compromise. If they are unable to do so, they appoint an elder from another clan to settle the dispute.

After a verdict is reached, the criminal must compensate his victim the appropriate amount. If he is unable or unwilling, his extended family must pay the compensation. Every Somali is born into an insurance group based on their lineage to a common great-grandfather. Out of their own self-interest these insurance groups help enforce the judgment on wrongdoers. When an individual becomes particularly troublesome, a family can publicly declare that the person is no longer a member of their group, effectively making the person an outlaw. Outlaws must find another insurance group willing to sponsor them, or they are expelled from the larger clan. In cases in which more formal enforcement of the law is necessary, clan elders can call for all

\footnotetext{
${ }^{4}$ This section on Somali Law draws on Van Notten (2005).

${ }^{5}$ See Van Notten 2005: 70-71 for a more complete listing of payments.
} 
clansmen to form a posse to enforce the verdict; clansmen are obligated to answer the call.

Since each Somali court is independent of the others, they often interpret customary law differently. Within clans, differences of interpretation are usually quickly resolved, but this process can take much longer on the national level (Van Notten 2005: 36). Ultimately, through the resolution of disputes the law is discovered and conflicts in interpretation are resolved. Although the interpretation of the law stems from clan elders, the clans are not de facto governments. Upon becoming an adult, individuals are free to choose new insurance groups and elders. In addition, individual clans are not geographic monopolies. As Little (2003: 48) notes, "In no way does the geographic distribution of clans and sub-clans correlate with neatly defined territorial boundaries... drought and migration blur the relationship between clan and space."

While local cleric courts have become the dominant source of law in some regions, and Koranic law is traditionally applied to marriage and inheritance, the common law of Xeer and the accompanying elder dispute resolution and insurance groups are the main source of law in Somalia. The Xeer shares common attributes focusing on restitution and the protection of life and property with English common law and other polycentric systems. ${ }^{6}$ The traditional Somali legal system existed unofficially during the reign of Siad Barre, and since state collapse it has emerged to provide some level of the rule of law on which coordination in the Somali economy could be based.

\footnotetext{
${ }^{6}$ In particular its blood payment system is reminiscent of Friedman's (1979) description of law during Iceland's medieval period of statelessness.
} 


\section{Money}

During the late 1980s the Somali central bank expanded the money supply while attempting to gain seigniorage revenue for the government. The amount of currency in circulation expanded from 3.8 billion Somali shillings (SoSh) in 1985 to more than 155.7 billion SoSh in $1990 .^{7}$ During this time the difference between the official exchange rate and black market rate was as large as 275 percent (Little 2003: 7). The Somali central bank and the rest of the state-owned banking system disappeared with the collapse of the central government. Demand deposits disappeared, and inside money contracted by 54 percent. Despite the collapse of the central government, Somalis continue to accept pre1991 Somali shillings. The collapse and continued absence of the central government have not shaken people's expectation that the currency has an exchange value.

Since 1991 no central bank has existed to issue currency. Since the collapse four currencies have been introduced in Somalia. The system that has emerged does not reflect the type of private competing monies envisioned by theorists like Hayek (1976), however. The Na' shilling was first introduced in north Mogadishu in 1992 and then again reissued in 2001. A distinct note that does not resemble the pre-1991 notes, it has failed to gain widespread acceptance and circulates mostly within a single clan. The region of Somaliland has established its own central bank and issues a currency intended to circulate as the exclusive currency in its territory. A south Mogadishu leader issued Balweyn I bank notes in 1997. These notes are widely accepted forgeries of the pre-1991 central bank notes. Similarly, the Puntland administration has issued its own forged pre1991 Balweyn II SoSh. By 2003 new bank notes and forged currency accounted for about 80 percent of all currency in circulation. 
Although the Balweyn notes can be distinguished from pre-1991 SoSh, the Somalis have treated them all as the same currency. Unlike a competitive banking system with distinct currencies in which competition could limit the amount of inflation and seigniorage individual issuers could achieve, the competition in Somalia is for seigniorage in the same currency. One would expect this competition to lead to an infinite level of inflation and ultimately public abandonment of the currency. Somalis, however, refuse to accept denominations larger than those that existed in 1991. This has constrained inflation and actually allowed for a relatively stable monetary system to emerge.

Mubarak (2003) estimates that it costs $\$ 0.03$ to print and import new bank notes to Somalia. When the first Balweyn notes were printed in 1997, the largest denomination SoSh (1000) traded for about $\$ 0.12$. By late 2001 competition for seigniorage had driven the SoSh 1,000 note down to about $\$ 0.04$. At this exchange rate printing SoSh 500 notes was no longer profitable, and the SoSh 1,000 notes were down to nearly their commodity cost, making further printing of them no more profitable than other investments. After the initial bout of inflation, Mubarak reports that "there is no sign of significant inflation let alone an infinite one," and that "Since July 2001... consumer prices have stabilised. If the market exchange rate movements are an indication of price stability... the Somali shilling has appreciated slightly since the importation of new reprints slowed" (2003: 323). Though very different than the currencies advocated by those who advocate 100 percent commodity backed currencies, the effect of the competition for seigniorage coupled with the Somalis' failure to accept new, higher denominations has led to the creation of a stable 'commodity currency' worth its paper, ink, and transport costs.

\footnotetext{
${ }^{7}$ This section draws on Mubarak (2003). Statistics come from this source unless otherwise cited.
} 
While such a currency provides some stability, it is not without its problems. To make purchases of any significant size, large bundles are needed. For this reason the SoSh is used alongside U.S. dollars in Somalia. The SoSh is used for small transactions while the dollar is used for larger ones. The Somali people's continued use of the SoSh in absence of a state monopoly is testament to the currency's relative success, as is the fact that it circulates with easy convertability 50km inside the Ethiopian border while the Ethiopian Birr has little circulation in Somalia (Little 2003: 144).

Financial services are provided in Somalia through many of the same informal institutions that existed under the national government. As Little notes, "With formal economic institutions and financial systems exceedingly fragile in the 1980s, their subsequent collapse in Somalia meant little for most of the population" (2003: 9). Loans are traditionally secured through family members, not banks. Money transfers are handled through the Hawala system, which allows Somalis to transfer money within the country and from abroad. Typically recipients are asked a series of questions based on clan lineage to verify their identity when they receive funds. This system successfully moves $\$ 500$ million to $\$ 1$ billion dollars a year into Somalia; commission rates are typically around 5\% (Coyne 2006: 22). Unfortunately, one of the major transfer houses, Al Barakaat, was shut down after the 2001 terrorist attacks on the United States because of suspected links to terrorist organizations. However, as Little explains, "while a resident of Somalia still has little access to formal banking and financial institutions, access to other financial facilities actually has improved with the collapse of the state (2003: 144). 


\section{Conclusion}

Since the collapse of its central government, Somalia has not become an anarchocapitalist utopia resembling those described by theorists such as Rothbard (1973) and Friedman (1989). However, most African states do not come close to approaching many theorists' views of an ideal state either. In a comparative institutional comparison given existing culture, ideology, history, geography, income, and resources, the interesting question is how well does Somalia function compared to realistic alternatives. Menkhaus summarized the Somali view of the state by writing,

The revival of a state is viewed in Somali quarters as a zero-sum game, creating winners and losers in a game with potentially very high stakes. Groups which gain control over a central government will use it to appropriate economic resources at the expense of others, and will use the law, patronage, and the monopoly of legitimate use of violence to protect this advantage. This is the only experience Somalis have had with centralised authority, and it tends to produces risk-aversion and to instigate conflict rather than promote compromise, whenever efforts are made to establish a national government (2003: 408).

Given this Somali view of the state, the reemergence of a national government would quite likely produce a "vampire state" that would not provide social order but would instead suck the life out of the economy. Ayittey recently wrote that the modern nation state is largely incompatible with traditional indigenous African culture and that,

"The rogue African state should be left to the fate it deserves - implosion and state collapse" (2007: 238).

This paper has explored the consequences of state collapse for a country that existed under the rule of a vampire state. Far from chaos and economic collapse, we find that Somalia is generally doing better than when it had a state. Basic economic order is possible because of the existence of a common law dispute resolution system and a non- 
state monetary system. On that foundation we find that urban business and commercial activity is possible and that the pastoral sector has expanded. This paper's main contribution to the literature on Somalia's living standards has been to compare them to those of 42 other sub-Saharan African countries both before and after the collapse of the national government. We find that Somalia's living standards have improved generally and that they compare relatively favorably with many existing African states.

Importantly, we find that Somali living standards have often improved, not just in absolute terms, but also relative to other African countries since the collapse of the Somali central government. 


\section{References}

Ali, Abdi. (2004) “Coke Plant Heralds New Beginning in Somalia.” African Business Journal, August/September.

Amound University (2006) www.amouduniversity.net

Ayittey, George (1998) Africa in Chaos. New York, NY: St. Martin's Press.

Ayittey, George (2007) “The African Development Condundrum.” in Making Poor Nations Rich: Entrepreneurship and the Process of Development. Benjamin Powell (ed.), Palo Alto, CA: Stanford University Press.

Besteman, Catherine (1996) "Representing Violence and 'Othering' Somalia." Cultural Anthropology, Vol. 11, No. 1 February: 126.

Besteman, Catherine (1996) "Violent Politics and the Politics of Violence: The Dissolution of the Somali Nation-State." American Ethnologist, Vol. 23, No. 3 August: 581.

Country Watch (2005) Somalia Review. http://www.countrywatch.com/

Coyne, Christopher (2006) "Reconstructing Weak and Failed States: Foreign Intervention and the Nirvana Fallacy." Foreign Policy Analysis, Vol. 2: 343-361.

Davidson, Jim (2001) “Somalia And Anarchy." Formulations, Free Nation Foundation; Issue 30; Summer 2001.

DHL (2006)

www.dhl.com/publish/g0/en/information/countrydetails.high.html?CTRY_CODE=so

Economist (2005) The Economist. December 24. p. 89.

Farzin, Hossein (1988) Food Import Dependence in Somalia: Magnitude, Causes, and Policy Options. World Bank Discussion Papers No. 23. Washington, DC: The World Bank.

Federal Research Division (1993) Somalia: Country Studies. "The Segmentary Social Order." Library of Congress.

Friedman, David (1979) "Private Creation and Enforcement of Law - A Historical Case." Journal of Legal Studies, Vol. 8, No. 2: 399-415.

Friedman, David (1989, 1995) The Machinery of Freedom. La Salle: Open Court 
Publishing Company.

Hayek, Frederick (1976, 1990) Denationalization of Money - The Argument Refined: An Analysis of the Theory and Practice of Concurrent Currencies. London, UK: The Institute of Economic Affairs.

Leeson, Peter (2006) "Better Off Stateless: Somalia Before and After Government Collapse." Working Paper. West Virginia University.

Little, Peter (2003) Somalia: Economy Without a State. Bloomington, IN: Indiana University Press.

Menkhaus, Ken (2003) "State Collapse in Somalia: Second Thoughts." Review of African Political Economy, Vol. 97: 405-422.

Mubarak, Jamil (1997) “The 'Hidden Hand' Behind the Resilience of the Stateless Economy of Somalia." World Development, Vol. 25, No. 12: 2027-2041.

Mubarak, Jamil (2002) "A Case of Private Supply of Money in Stateless Somalia." Journal of African Economies, Vol. 11, No. 3: 309-325.

Nenova, Tatiana and Tim Harford (2004) "Anarchy and Invention." Public Policy for the Private Sector, World Bank Group. Note Number 280. November.

Rothbard, Murray $(1973,1996)$ For a New Liberty. San Francisco, CA: Fox \& Wilkes.

Schraeder, Peter (1986) "Involuntary Migration in Somalia: The Politics of Resettlement." The Journal of Modern African Studies, Vol. 24, No. 4: 647.

Somaliland in Figures (2002) http://www.so.undp.org/pdf/somaliland\%20figs.pdf

Van Notten, Michael (2005) The Law of the Somalis. Ed. Spencer Heath MacCallum. Trenton, NJ: Red Sea Press.

Winter, Joseph (2004) “Telecoms Thriving in Lawless Somalia." BBC News. Nov 19. Accessed on www.newsvote.bbc.co.uk/mpapps/pagetools/print/news. bbc.co.uk/2/hi/africa/4020259.stm

World Bank (2006) World Development Indicators Online. Washington, DC: The World Bank Group. 